Journal of Social and Development Sciences

Vol. 3, No. 7, pp. 229-244, July 2012 (ISSN 2221-1152)

\title{
The Living Conditions of Female Head Porters in the Kumasi Metropolis, Ghana
}

\author{
Theresa Yaaba Baah-Ennumh ${ }^{1}, 1{ }^{1}$ owusu Amponsah*, ${ }^{2}$ Martina Owusu Adoma \\ ${ }^{1}$ Department of Planning, KNUST, Kumasi, Ghana \\ ${ }^{2}$ Saint Louis Senior High School, Kumasi, Ghana \\ *amponsah_owusu@yahoo.co.uk
}

\begin{abstract}
Migration of the economically active population from northern to southern Ghana is an old age phenomenon sustained by the incessant perception of abundant job opportunities in the south. Recently, young girls and women who migrate to work as head porters have dominated the phenomenon. The purpose of this paper was to examine the reasons for their continuous migration to the Kumasi Metropolis and the conditions under which they live and work. Complementary data from 100 head porters and five institutions revealed that most of the head porters were children (under age 18) living in harsh and hazardous conditions which include poor housing, health care delivery, nutrition, and water and sanitation. The authors conclude that the relentless desire of young girls and women to work as head porters in the south and the associated poor living conditions could be minimised if youth policies are implemented with direct focus on capacity building for the head porters. The long-term remedy to the menace, the authors maintain, lies with socioeconomic development of the rural-supplying areas to bridge the development gap between the urban and rural areas.
\end{abstract}

Keywords: Migration, Head Porters, Female, Living Conditions

\section{Introduction}

Background to the Paper: The monetisation of society has created a precondition for human beings to work and earn income to meet their necessities of life such as food, shelter and clothing. Thus, given sufficient opportunities for personal fulfilment, and a more equitable distribution of resources and wealth, many people would prefer to live close to relatives and within their cultural milieu (Martin, 2003; Opare, 2003). Martin (2003) describes the tendency of people to stay with their relatives as intertia and argues that it is the foremost form of migration control. However, the absence of such an ideal world compels people to migrate to expand the range of socioeconomic livelihood opportunities available to them (Klein, 2000 cited in Opare, 2003). This increasing drive by people to meet their daily needs and improve their living conditions results in individuals migrating from their places of socio-cultural comfort and breaking their family ties in search for life enhancing opportunities. The migrants choose economic opportunities at their destinations over the socio-cultural comfort at the origin. The point to note is that migration is not a recent phenomenon. According to Nabila (1985 cited in Kwankye, 2011) and Lobnibe (2010), migration from the northern part of Ghana to the middle and southern belts began quite early as the colonial authority was actively involved in attracting labour from the northern savannah agro-ecological zone. Consequently, the theoretical explanations of migration have had a long history, dating far back into the 1880s Ravenstein's "migrationdistance hypothesis" and the subsequent "push and pull" theoretical framework developed by Lee (1966) as well as the Harris-Todaro's migration model (Todaro and Smith, 2012). In the view of Ravenstein, migrants move from areas of low economic opportunities to areas of endowment. Revenstein further indicated that the incidence of migration inversely related to distance (Bilsborrow et al, 1984). The economic reason remains as a major factor sustaining labour migration in the $21^{\text {st }}$ century development. However, the distance as hypothesised by Ravenstein holds to some extent. Technological advancement, which has rendered the world a global village, goes to challenge the distance barrier in the hypothesis. Movement is not as challenging as in the $19^{\text {th }}$ century when the hypothesis was put forward.

In his push and pull theoretical framework, Lee (1966) also explained that deteriorating factors in the places of origin (push factors) of migrants and/or attractive opportunities (pull factors) in the destination of migrants are the main triggers for migration; a situation which is still valid in the $21^{\text {st }}$ century. The Harris- 
Todaro Model of migration also posits that migration is stimulated by rational economic considerations. Todaro and Smith (2012) reveal that the decision to migrate depends on expected urban-rural real wage differential. With the perception that urban real wages are higher than that of the rural areas, labour drifts to these urban areas. The authors note that economic reason is the major factor that explains people's decision to migrate. There has been a surge in female migration over the recent two decades, especially in Asia and Africa with an increase in the migration of young girls. This is in contrast with migration trends in the 1880s where females were said to be engaged in only short distance migration. It was believed that women and children were forced to accompany the head of the household (usually husband) whenever there was any form of household migration (Ravenstein, 1885 cited in Yeboah, 2008). According to the Caritas Internationalis (2012), since the early 1980s, increasing number of women has been migrating on their own to take up jobs in other areas. Subsequently, more than half of all migrants today are women and girls, with many of them migrating independently rather than as part of a family (Kwankye et al, 2007). The contribution of women to migration in recent times has given birth to the term "feminisation of migration" which has gained currency in development discourse. The Ministry of Women and Children's Affairs (MOWAC) estimated that as many as 40,000 porters most of whom are girls under age 18 years lived on the streets in major cities, including Accra, Kumasi, and Takoradi. In a similar vein, the US State Department of Trafficking in Persons, estimated that over 30,000 children are working as head porters on the streets of Accra alone, a phenomenon which is considered as a major setback to the attainment of the Millennium Development Goals (MDGs) (United States Department of State, 2009).

Opare (2003) adds that the number of the head porters increase every day. Majority of these children lack almost all the basic needs of life: education, shelter, health care, adequate nutrition, and personal safety and are often targets for exploitation, abuse, threats and violence (UNICEF, 2007). Premised by the north's comparative advantage in cereal cultivation, the Government of Ghana has sought to encourage all-yearround farming with the construction of irrigation dams (Inkoom and Nanguo, 2011). Inkoom and Nanguo (2011) believe that the effective utilisation of the irrigation dams would reduce the migration of labour from the northern to southern Ghana. The Government of Ghana has reinforced her free Compulsory Universal Basic Education (fCUBE) policy with social interventions such as the Capitation Grant, School Feeding Programme and Free School Uniforms. Her intention is to retain the children in school to forestall their migration to the south to engage in head porterage. Despite the increasing recognition and efforts by successive governments to discourage head porterage, many more young females are leaving their homes and finding solace on the streets of major cities (Opare, 2003). There is therefore an urgent need for a sustainable solution to the menace. This underscores the necessity to empirically investigate the phenomenon with the primary objective of establishing the motivations behind the young females' migration and their living conditions in their destination. The paper is structured into five parts. Part one gives a general overview of the paper with details of the study's background and the research objectives, which define the contextual scope of the investigation into phenomenon. Part two presents the results of the authors' desk study, which uncovered the relevant theoretical exposition of migration particularly in the $21^{\text {st }}$ century. In part three, the authors explain the empirically strategy they used to collect and analyse data to address the research objectives. Part four presents and discusses the findings of the survey while part five examines the way forward in finding a lasting solution to the menace.

In the study, the authors primarily sought to examine the living conditions of female head porters in the Kumasi Metropolis. The authors achieved this objective through the following specific objectives:

- To examine the causes of the migration of young men to the Kumasi Metropolis to work as head porters;

- To assess the living conditions of the head porters and the challenges arising out of such conditions; and

- To make suggestions on policy options to reduce the identified challenges and the possible way forward towards reducing the head porters menace/problem.

\section{Literature Review}

History of Head Porterage in Ghana: Traditionally, head porterage has been a major means of transporting goods in Ghana the absence of modern modes of transport. In contributing to having clarity on the history of 
head porterage in Ghana, Kwankye et al (2007) indicate that the activity precedes colonisation. To Agarwal et al. (1997), domestic head porterage was historically women's activity in Ghana. Rural women in Ghana and other parts of Africa have been known to transport agricultural produce by head porterage for household consumption and/or for sale. This practice is still common in both urban and rural areas in contemporary Ghana. Even with the introduction of modern and intermediate modes of transport in recent times, head porterage is still popular particularly in the developing world (Baah-Ennumh and Adom-Asamoah, 2012). The activity's economic dimension is even enough to pull surplus labour in the rural less endowed areas to the cities. Baah-Ennumh and Adom-Asamoah (2012) add that the lack of convenient modes of vehicular transport between sales points and bus terminals in the central business district of Kumasi Metropolis has fuelled the phenomenon. Thus, head porterage remains the cheapest and most convenient form of transport between market places and bus terminals. Although head porterage in colonial Ghana by women is a known practice, it did not have an economic orientation since it was done largely for domestic purposes. This reinforces the claim that head portage has been part of human civilisation. The phenomenon has however evolved from its general traditional sense to an economic activity that employs a section of the economically active age group. The evolution came with the male migrants from the Sahelian West Africa countries, mainly from Mali (Kwankye et al., 2007). It was virtually male dominated and those who engaged in it were called "kaya".

After the Aliens Compliance Order of 1969, the 'kaya' business almost died out as those who practiced it were affected by the expulsion order (Kwankye et al., 2007). The Alien Compliance Order expelled all foreigners who did not have genuine permits to stay and work in Ghana. The gap created by the exit of the foreigners was then filled by Ghanaians with little alteration to the trade; though men still carried the heavy loads and preferred to transport the loads on hand trucks instead of their heads. With time, congestion in major markets caused by unplanned buildings and structures and human and vehicular traffic made it difficult for the effective use of trucks, thus calling for a change to a mode of transport that was able to function effectively in the congested markets. Head porterage thus re-assumed a place in the transportation of goods from one part of the city to another; providing an employment niche for young people migrating into the cities. In recent times, the economic activity is dominated by young females popularly called "Kayayei" a term which literally means "female head porters". According to Kwankye et al (2007), kayayei is a local term commonly used by the Gas (an ethnic group in Ghana). It is derived from two words; "kaya" from Hausa which means goods and "yoo" from ${ }^{1} \mathrm{Ga}$ meaning woman or girl. Kayayei is a plural form of Kayayoo (Coffie, 1992 cited in Duduchoge, 2003). The term Kayayei is thus construed as a migration legacy, which explicitly brings out the connection between internal and international migration (Kwankye et al., 2007).

Factors that have Promoted Head Portage in Ghana: Literature on migration (both internal and external) seems to point to a consensus that, throughout the globe, economic considerations are the principal triggers for migration (source). Besides the economic considerations, social and political factors are also some of the triggers of migration. These social factors include movement; to join spouses, to be free from burden posed by family members, to enjoy social services such as education and health from social amenities abundant in the urban areas and religious reasons. The political factors also include asylum, freedom from conflicts. Anzagra and Yeboah (2012) identified that more than 50 percent of the child migrants they covered in their study migrated in order to find jobs in the Kumasi metropolis. Furthermore, 46.7 percent of the children migrated in order to fend for themselves because they claimed their parents were poor and could not take care of them. Their findings were consistent with Kwankye's view that the main reason for the children's decision to migrate is 'independence and money' (Kwankye, 2011). Similarly, Kese (2004) revealed a less known but very important trigger of young females moving to the cities in southern Ghana to work as head porters. Kese (2004) argues that the architectural designs of markets in the Ghanaian cities which do not allow for the use of intermediate and modern modes of transports in the congested markets, promote the carriage of goods by human beings. The socio-cultural environments in which female porters live in Ghana are also known to influence the migration of girls to cities. Many migrant girls in Ghana come from poor rural communities in which children start earning their own independent incomes quite early, as well as contributing to family income. Thus, young girls are encouraged to earn some incomes for their own consumption and upkeep. Besides the need for income, the out-migration of unmarried females to the cities of Accra and Kumasi is also

\footnotetext{
${ }^{1}$ It is a language spoken by the Gas located in the Greater Accra Region of Ghana.
} 
variously linked to females escaping from the traditionally ascribed status such as obeying male kinsmen, or excessive hard work or customary practices such as female genital mutilation or arranged marriages (Whitehead and Hashim, 2005; Awumbila, 2007). These socio-cultural factors make it very complex and challenging to totally eradicate the migration of young girls to the cities to work as head porters.

The authors note that myriad social, economic, political and cultural factors underpin people's decision to migrate. While several migrants move voluntarily to improve their living conditions, other moves in order to flee from outmoded and inhuman cultural practices.

Theoretical Underpinning of Migration: These causes of migration are explained by several theories on migration. Most studies on migration for example consider the "push and pull" theoretical framework developed by Lee in 1966 as one of the major theoretical underpinning for rural-urban migration especially for head porterage (Yeboah, 2008). The theory indicates that 'push' factors exist at the point of origin and act to trigger emigration. The push factors include, poverty, lack of adequate infrastructure in rural areas, parental neglect, breakdown of family structures, lack of education and employment opportunities, low family incomes, peer influence and debilitating socio-cultural practices. On the other hand, the 'pull' factors' include the perceived availability of jobs at the destination, better infrastructure/social services and food and freedom from family pressure (Opare, 2003; Kese, 2004; Awumbila, 2007; Berg, 2007; Kwankye et al., 2007). This means that migration can only occur if the reason to emigrate (the push) is remedied by the corresponding pull factors at an attainable destination (Muñiz-Solari et al. 2010 cited in Solem et al. Eds 2011). The theory however stipulates that the flow of migrants between two places may not totally develop if intervening opportunities exist between them; that is, the presence of other places between an origin and destination point to which one could migrate. Two issues emerge from the discussion of the causes of migration with the Lee's theory of migration as the underpinning.

- That a combination of socioeconomic and political reasons influences people's decision to either emigrate (push factors) or in-migrate (pull factors); and

- That the destination of the migrants is the shortest destination which has the socioeconomic and political answers the migrants seeks.

The intervening opportunity in the case of child migrants from Northern Ghana to the south could have been the ${ }^{2}$ Tamale metropolis or the ${ }^{3}$ Sunyani municipality. However, relative to the Kumasi metropolis which is the commercial hub of the northern sector of Ghana, the interventions from Tamale and Sunyani are not enough to prevent the child migrants from choosing Kumasi as their destination (Ghana Statistical Service, 2005). Thus, the Kumasi metropolis' endowment in social and economic infrastructure coupled with its proximity to the north relative to Accra, Sekondi Takoradi and a host of other cities in the north makes it the first destination for migrants including the children. In sum, the Lee's push and pull theory has affirmed the economic dimension of migration alluded to by the authors of this paper in the above. What is evident is that economic reasons are the major triggers of migration across the globe. The "survival strategy approach" proposed by Stark (1984) and "household strategy approach" by Chant (1998) further explain the economic underpinning of migration. The survival strategy asserts that the migration of labour from rural areas is essential for the survival of urban capitalism. Stark (1984) asserts that rural families use rural-urban migration as a wealth accumulation strategy through remittances received from the migrants. Thus, head porterage can be said to be mutually beneficial to both the head porter and their operational areas and should not be entirely regarded as a nuisance. This claim is supported by Kwankye et al (2011) and Adu-Okoree (2012) claim that that some of the young girls migrate to the cities to earn incomes to expend on cooking and other household wares. Their possession of these wares is a demonstration of their readiness for marriage. Adu-Okoree (2012) explains that "every woman is expected to have a quantity of cooking and dining sets to decorate their rooms. The more of these items a woman has, the more attractive she is and therefore gets the best of potential suitors". The authors note that economic and social reasons come to play to compel the

\footnotetext{
${ }^{2}$ Tamale metropolis is the capital of the Northern Region of Ghana. Northern region is one of the 10 administrative regions in Ghana.

${ }^{3}$ Sunyani municipality is the capital of the Brong Ahafo region of Ghana.
} 
young girls in question to migrate to the cities. Their decision to migrate to work and earn income is "economic" while the intention is to be ready for marriage which is a social reason.

The Classical Economists also argue that rural inhabitants are attracted to the urban areas by high industrial wages. This is the premise of the modernisation theory. Furthermore, the Urban Bias Theory indicates that that the concentration of economic opportunities (investments) results in the exodus of rural labour to the urban areas. This bias in favour of city has created a disparity between country and city (in terms of consumption, wage and productivity levels), and thus translating into a higher standard of living from urban citizens which draws migrants from poorer (rural) areas to the cities. The Harris-Todaro Model of migration model also explains that migration is stimulated by rational economic considerations. Todaro and Smith (2012) highlights that the decision to migrate depends on expected rather than actual urban-rural real wage differential. In conclusion, the authors note that the consensus among the theories on migration is the economic consideration. This is summed up by the Ghana Statistical Service (2005) citing Kelly and Williamson (1984) that rural-urban migration is more a function of opportunities in the cities than it is of population pressure from the rural areas as perfectly explained by the urban bias theory.

\section{Methodology}

The study focused mainly on female head porters operating in the Kumasi metropolis. Kumasi is the second largest city (coming only after Accra) in Ghana and serves as a major administrative and commercial centre especially for the middle and northern belts of Ghana. This makes it a good business destination and a hub for both internal and international migrants in Ghana, and the West African Sub region. Kumasi's strategic location also makes it a profitable location for head porters to operate as they find a lot of travellers and shoppers' luggage to carry, hence its choice as a study area for this research.

Sampling Procedure: The researcher intuitively selected 100 head porters for the study. The sample size was determined by intuition because of the lack of up-to-date data on the number of head porters operating in the metropolis. The lack of a sampling frame constrained the determination of the sample size using a more objective approach (e.g. mathematically). Anzagra and Yeboah (2012) had already identified that the female head porters lived in groups with each group having a leader. Adoma (2009) had also identified four clusters within the Kumasi metropils where head poterage is concentrated. These clusters were the Race Course, Kejetia, Adum and Central Market areas all within the central business district of the metropolis. The researchers adopted the snowball sampling approach, where one subject of investigation leads the investigator directly or indirectly to another subject, to identify the leaders of the groups. The strong social networks among the head porters and their unwillingness to communicate with strangers out of suspicion made this sampling technique the most appropriate for the study. Through this approach, 20 group leaders were identified, five from each of the four clusters. The researchers then selected the members of the groups using the simple random sampling approach (i.e. lottery without replacement). The researchers operationalised the simple random sampling techniques by writing the names of the members of each identified group on pieces of paper and placed in a box. They were then drawn until five members were selected from each group. In all 20 groups of head, porters were covered. The selection of the institutions (refer to subsection 3.2) covered by the research was purposive owing to the reason that the researchers had prior information of their involvement with head porters in the cities of Ghana.

Sources and Methods of Data Collection: The researchers used information from both secondary and primary sources to examine the living conditions of the female head porters in the Kumasi metropolis. The secondary sources, obtained from published and unpublished scholarly works in books, peer-reviewed journal and conferences, provided the theoretical and conceptual framework that underpinned the research. The historical development of head porterage in Ghana was also obtained from literature. The secondary data were collected through desk study. The primary data were gathered through direct interviews using semistructured questionnaires and interview guides with the sampled female head porters. Through face-to-face interviews, 100 female head porters were covered. The researchers also observed and described the physical living conditions of the head porters. For instance, the nature of dwelling units and resting places, and environmental conditions were observed. The outputs are the pictures inserted in the paper as Figures (refer to Figures 1, 3 and 4). Five institutions namely, the Kumasi Metropolitan Assembly (KMA), the Street Children 
Development Foundation (SCDF), the Street Children Project (SCP), Centre for the Development of People (CEDEP) and the Department for Children under the Ministry of Women and Children (MOWAC), were interviewed. The researchers used interview guides to obtain the responses from the five institutions covered in the research.

\section{Data Analysis and Presentation}

The data obtained from the units of analysis were both quantitative and qualitative. The quantitative data were analysed using the Statistical Package for Social Sciences software (SPSS) version 14. The SPSS version 14 was used to generate the frequencies, percentages and averages (arithmetic mean) used for the analyses of the research variables such as the ages, sex, educational levels, origin, reasons for migrating duration of stay and income and expenditure levels. The qualitative data were analysed descriptively. The head porters' dwelling units and environmental conditions were described from their perspectives. The quantitative and qualitative data were all triangulated with the findings of research works which predated this. The discussion was intended to identify the similarities and differences on what is known about the living conditions of the head porters.

Background characteristics and living conditions of the Head porters: This section of the paper presents the socio-demographic characteristics of the sampled female head porters in the Kumasi Metropolis. It highlights characteristics such as; age, educational and marital status, ethnicity, length of operation as head porters and their living conditions.

Background Characteristics: The survey results indicate that $52 \%$ of the female head porters were between the ages of 15 and 19 years with a majority (60\%) of them below age 18 as indicated in Table 1 . This finding tallies perfectly with the Anzagra and Yeboah's (2012) observation that about $60 \%$ of the head porters in the Kumasi Metropolis were children aged less than 18 years. The finding is a confirmation of Feigben (2010) claim that child labour persists in Ghana. The very young age of these porters makes them susceptible to various forms of risks associated with child labour and consequently affects their personal and educational development. The survey results indicated that only $34 \%$ of the head porters had attained basic education. The remaining 66\% had no formal education. To Anzagra and Yeboah (2012), the very young age at which these porters begin their trade greatly accounted for their general low educational levels as the years that should have been spent in school are spent on the streets as head porters. For instance, Table 1 shows that all the children below 15 years (17\%) were supposed to be currently enrolled in school. They have however migrated to Kumasi to work as head porters. Kwankye (2011) reveals that the independent north-south child migration has become an investment for parents. By implication, children are supported either directly or indirectly by their families to migrate to the cities. Thus, despite the free education which is supported by social interventions such as the Capitation Grant, the School Feeding Programme and just recently the Free School Uniform Programme, the children are not enrolled in school.

Table 1: Age Distribution of the Head Porters

\begin{tabular}{lll}
\hline Age (years) & Frequency & Percentage \\
\hline $10-14$ & 17 & 17.0 \\
$15-19$ & 52 & 52.0 \\
$20-24$ & 20 & 20.0 \\
$25-29$ & 7 & 7.0 \\
$29-34$ & 2 & 2.0 \\
$35-39$ & 0 & 0.0 \\
$40-44$ & 1 & 1.0 \\
$45-49$ & 1 & 1.0 \\
Total & 100 & 100.0 \\
\hline
\end{tabular}

The study results also indicate that $93 \%$ of the head porters were from Northern Ghana with $65 \%$, $24 \%$ and $4 \%$ being Dagombas, Gonjas and Mamprusis, respectively. In assessing the coping strategies of independent child migrants from Northern Ghana to southern cities, Kwankye et al. (2007), observed that majority of the migrants were from the Northern Region of Ghana. Adepoju (2005 cited in Kwankye, 2011), Ghana Statistical 
Service (2007), Awumbila (2007) and Kwankye et al. (2007) attribute the north-south migration to the northsouth development dichotomy. With Kumasi as one of the economically endowed cities in Ghana and by its proximity to the north, it has become a favourable destination for child migrants (Ghana Statistical Services, 2005; Kwankye et al., 2007). The study result is a confirmation of this. The analyses revealed that economic reason (viz. "look for money" and "for employment") was the main reason (accounted for 69\% of the responses) why the children migrated to the cities in the southern part of Ghana. A triangulation of the economic reason for migration with Kwankye's (2011) observation that children's migration appears to be a strategic economic investment by many parents against poverty implies that children migrate with the hope of supporting their households. Hashim (2005) found that the decision by children to migrate is most often influenced by parents, relatives, and friends based on the benefits they (parents) are likely to obtain from the migration of their children. The children migrate at the expense of their education to work and support themselves and their families.

In terms of the duration of stay in the metropolis, the data analyses revealed that $81 \%$ of the head porters had lived in the city for less than a year; with some staying for less than a month or even a week. Only $2 \%$ had lived in the city for 5-10 years. The relatively short stay of the porters in the city can be explained by the fact that most (47\%) of them migrate to the city purposely to search for money to buy kitchen wares and sewing machines and therefore return home after saving enough money to obtain these needs. This finding is supported by Kwankye et al. (2009) and Anzagra and Yeboah (2012) who identified that the young women migrate to Kumasi to work. They save from their earnings to buy kitchenwares to be ready for marriage. Seventy-nine percent of the porters were not married (single) while twenty $21 \%$ were married, thus explaining why the search for money to buy kitchen wares for marriage was a common reason mentioned for migrating to the city. Twelve percent of the unmarried head porters however indicated that they had boyfriends and concubines. Fourteen percent of the porters interviewed had one child each, 3\% had two children each, $2 \%$ had four children each, and $1 \%$ had six children. Here, the immediate cause of migration is economic (i.e. work to save) and the long-term causal factor is social (i.e. their desire to be ready for marriage). This supports the discussion in subsection 2.2 that myriad factors underpin people's decision to migrate.

Living Conditions of the Head Porters: The living conditions of the head porters were the focus of the study. The nature of shelter, food, healthcare, and water and sanitation that constituted their basic lifesustaining needs was investigated. The investigation of the nature of houses revealed that $49 \%$ of the head porters lived in wooden shacks in the slums (see Figure 1), a finding which tallied well with King and Amponsah's (2012) observation that the slums are the hubs of migrants. These dwelling units do not have the basic household facilities such as bathhouses, toilet and kitchen. The survey identified that the shacks were inhabited by an average of four head porters who only cared about just enough space to sleep.

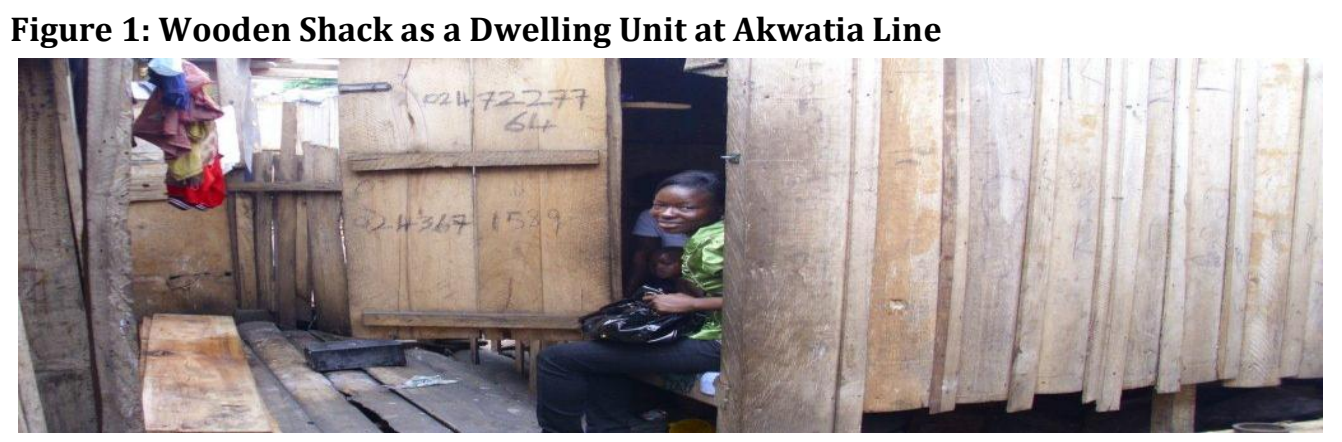

The others used as dwelling units were rented single room apartments in compound houses (14\%), shops $(20 \%)$ and the verandas of shops along the streets (3\%) (See Table 2). The head porters contributed to hiring the single room apartments in the compound houses. Azangra and Yeboah (2012) had earlier indicated that head porters who lived in formally rented rooms often stayed together in groups and contributed to the payment of the rental charges. King and Amponsah (2012) argue that slum dwellers are priced out of the formal housing systems because of low incomes. In support of this, the head porters who otherwise would not have been able to afford the rental charges on individual basis have been able to do so in a united front. 
The room occupancy rate was five persons per room in the compound houses which is about $67 \%$ higher than the national average room occupancy rate of 3 persons per room. Just as the occupants of the wooden shacks were less concerned about space in the rooms so were the occupants of single rooms in the compound houses.

Table 2: Types of Shelter Patronised by the Head Porters

\begin{tabular}{|c|c|c|c|c|c|c|}
\hline \multirow{2}{*}{ Type of Shelter } & \multicolumn{6}{|c|}{ Percentage of Head Porters } \\
\hline & & Kejetia & Race course & Adum & Central market & Total \\
\hline \multirow{2}{*}{$\begin{array}{l}\text { Single rooms in } \\
\text { compound houses }\end{array}$} & $\mathrm{N}$ & 5 & 2 & 3 & 4 & 14 \\
\hline & $\%$ & 20.0 & 8.0 & 12.0 & 16.0 & 14.0 \\
\hline \multirow{2}{*}{ Wooden shacks } & $\mathrm{N}$ & 15 & 7 & 14 & 13 & 49 \\
\hline & $\%$ & 60.0 & 28.0 & 56.0 & 52.0 & 49.0 \\
\hline \multirow{2}{*}{ Verandas } & $\mathrm{N}$ & 0 & 0 & 3 & 0 & 3 \\
\hline & $\%$ & 0.0 & 0.0 & 12.0 & 0.0 & 3.0 \\
\hline \multirow{2}{*}{ Shops } & $\mathrm{N}$ & 1 & 6 & 5 & 8 & 20 \\
\hline & $\%$ & 4.0 & 24.0 & 20.0 & 32.0 & 20.0 \\
\hline \multirow{2}{*}{$\begin{array}{l}\text { Abandoned } \\
\text { factory }\end{array}$} & $\mathrm{N}$ & 4 & 10 & 0 & 0 & 14 \\
\hline & $\%$ & 16.00 & 40.0 & 0.0 & 0.0 & 14.0 \\
\hline \multirow{2}{*}{ Total } & $\mathrm{N}$ & 25 & 25 & 25 & 25 & 100 \\
\hline & $\%$ & 100.0 & 100.0 & 100.0 & 100.0 & 100.0 \\
\hline
\end{tabular}

About $14 \%$ of the head porters lived in an abandoned factory which was used for the production of ink and chalk at the Kumasi Race Course. A further probe into this shelter revealed that the Street Children Development Foundation (SCDF) obtained permission from the Kumasi Metropolitan Assembly for the abandoned factory to be used by the head porters as shelter against the unfavourable weather conditions and threats from external factors. The study's findings indicate that except $14 \%$ of the head porters who lived in single rooms in compound houses, majority $(71 \%)$ of them lived in wooden shacks, shops or on the verandas of shops along the streets (mostly in Akwatia Line, Aboaba and Apagyahene) at night exposing them to the vagaries of the weather and several other risks such as harassment from street boys. The coping strategy is however to sleep in groups to offer support to one another in times of need. This to the head porters has proven to be an effective antidote to rapes from their male partners. They however admitted that pilfering is commonly reported when they live together. Again, the researchers observed that the occupants of wooden shacks and the abandoned factory live in unhygienic environmental conditions and lack most basic facilities that enhance human survival such as adequate water supply, toilet facilities and other life sustaining amenities. King and Amponsah (2012) explained that the lack of basic life sustaining facilities and services is owed to the occupation on lands outside the planning zones. They further revealed that the slum dwellers are neglected by the city authorities in the provision of services to the urban folks. The coping strategy then was their patronage of communal toilets and baths in the slums and the CBD. The head porters paid 10 pesewas per visit to the toilet facilities and 10-15 pesewas for taking a shower in the communal bathrooms. In the abandoned factory where about $14 \%$ of the respondents lived, the number of the head porters per room/chamber ranged from 2 persons to 110 persons with the average room occupancy of 27 persons per room. Their overcrowded and unhygienic living conditions as indicated in Figure 2 could make them vulnerable to sanitation-related diseases.
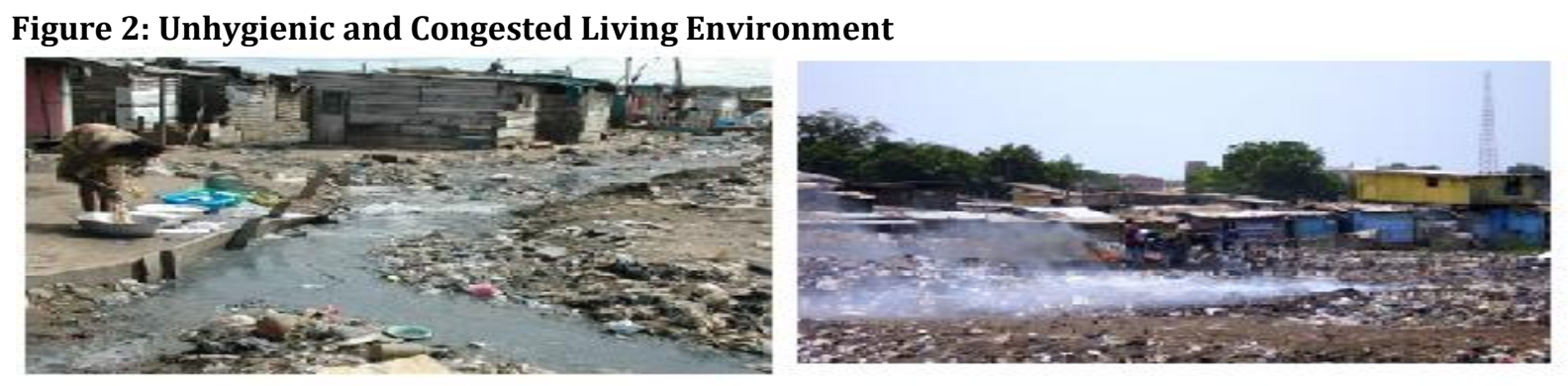

The survey revealed that the head porters paid weekly rent ranging from 25 pesewas to GH $\$ 1$. Forty-four percent of them paid 50 pesewas as weekly rent. Forty-eight percent of the head porters who stayed in the 
abandoned factory had access to electricity while $52 \%$ did not. Only $7 \%$ of the head porters slept on mattresses, while the others slept on materials such as mats (48\%), cardboard (22\%), cloth (11\%), floor (6\%) and carpet $(6 \%)$ reflecting the unhygienic and poor living conditions in which the head porters lived. When interviewed on their views about their places of abode, $45 \%$ of the head porters disclosed that they were insecure at their places of abode. They cited several reasons for the insecurity including theft of belongings by both colleagues and outsiders (18\%); insect bites such as bed bugs, ants and mosquitoes (15\%) which were evident in the skin rashes on the skins of some of the head porters, overcrowding (10\%), and harassment from landlords and males (2\%). Quaicoe (2005 cited in Kwankye et al., 2007) had earlier identified poor housing conditions, poor access health care services, inadequate sanitation facilities and harassment from male colleagues as the problems facing head porters in the metropolis. The survey results indicate that they problems are still prevalent in the lives of present day female head ports.

The researchers examined the health facilities patronised by the head porters and the common diseases they suffered from for the assessment of their health conditions. This was owed to the technical, legal and private issues surrounding the diagnosis of health status of individuals in the country. The results indicate that $87 \%$ of the head porters obtained health care from drug stores, pharmacy shops and drug peddlers while only $13 \%$ accessed health care from public and private clinics/hospitals. The use of non-prescribed drugs among the head porters confirms Kwankye et al. (2007) observation that head porters, having already determined what drugs they want to buy, visit chemical shops and buy drugs over the counter from the attendants who may not ask any questions. Anzagra and Yeboah (2012) add that self-medication seems to be more of the norm, particularly in Kumasi, often with symptoms diagnosed for them by friends or acquaintances who have suffered similar symptoms previously. In sum the study and similar others have revealed that self-medication is prominent among the female head porters in the metropolis. A further probe revealed that those who patronised the clinic/hospitals (13\%) had registered with the National Health Insurance Scheme (NHIS). This reveals the low subscription rate to the NHIS among the head porters. The common diseases suffered by the head porters were headaches $(40 \%)$, malaria $(13 \%)$ and body pains $(37 \%)$. They attributed these to the heavy wares they carry everyday in order to cope with the economic demands of the cities. Other diseases such as diabetes, rheumatism, eye problems and skin rashes were reported by $10 \%$ of the head porters. The authors were not able to objectively verify the diseases reported by the head porters because of the high incidence of self-medication among the head porters. Not ready to have children and/or being victims of sexual harassment, some of the head porters have indulged in unsafe abortions. An investigation revealed that the young girls enter into sexual relationships with their male counterparts in order to get monetary support from them (i.e. the males). The International Labour Organisation (ILO, 2004) had earlier observed that the head porters are coerced into exchanging sexual favours sometimes for simple basic human needs.

Teenage pregnancies among the girls are therefore common (Essel et al., 2007 cited in Yeboah and AppiahYeboah, 2009). A head porter revealed that she had witnessed six of such abortions from other head porters within two months. The authors snowballed 10 head porters who have ever aborted pregnancies for interview. The authors identified that majority of them were not ready for children while others did not know who the fathers of their children would have been if they had gone ahead to give birth. The latter reason is owed to the multiple sexual partners available to the head porters. The number of times the snowballed head porters had aborted pregnancies ranged from one to three. The researchers observed that the longer they stayed in the metropolis, the higher the tendency to abort a pregnancy. None of the head porters used recommended means of aborting pregnancies. All the head porters in question bought drugs from licensed chemical sellers to abort their pregnancies. All of them also indicated that the type of drugs they used for the abortion was recommended to them by their colleagues who had ever aborted their pregnancies. The head porters who are able to give birth safely usually sent their children to their parents back in at their places of origin. This only happens when the children are of age (usually five years and older). The Energy Sector Management Assistance Program (2011) identified that the head porters sent their wards back home to reduce the dependency on them and to be effective at the work. Between birth and the year the children are sent to the places of origin, one finds the head porters carrying both the loads and their children. The survey again revealed that those children who were found with their kayayei parents were not receiving the best of care from their parents. The reason as already indicated is that the parents themselves were not living in the best of conditions. Given the poor living conditions, the children could be exposed to several health problems 
which could be investigated by researchers from the medical perspective. From the initial observation made, most of the children were seen to be suffering from skin rashes believed to be caused by insects' bites.

Another indicator for the examination of the head porters' living conditions was their nutritional status measured by the type of food they ate. Food and nutrition is closely linked to the health status of people as nutritious food contributes to healthy lives. Majority (73\%) of the porters took three meals a day while 24\% and $3 \%$ took two and one meal a day respectively. Although majority of the head porters took three meals a day, about $44 \%$ of them did not take fish, meat, fruits or eggs in their meals. Only $33 \%$ occasionally added fruits to their diets. They attributed their inability to balance their diets to their low earnings. On the average, the head porters spent GH\$1.50 on food per day which was about ${ }^{4} 50 \%$ higher than the UN’s extreme poverty line of US $\$ 1.00$ per day. The survey revealed that about $95 \%$ of the head porters bought all their food from vendors who sold food along the streets. The remaining $5 \%$ bought their breakfast and lunch from the vendors but prepared their own dinner after close of work. Kwankye et al. (2007) had already identified that many head porters satisfied their hunger by buying food from street vendors. Further investigations revealed that the spent the bulk of their working hours from at the places of work and thus could not have time to cook their own meals. The analyses of the field data revealed that the head porters purchased their drinking water and the water they used for domestic chores. About $91 \%$ of them bought pipe borne water from private individuals at costs ranging from 10-15 pesewas per bucket (18 litres of cold water). They paid 10 pesewas to use the public bathrooms and 10-20 pesewas to use public toilets. This is consistent with the ESMAP's survey finding that communal facilities are patronised by the inhabitants of the slums who are mainly migrants due to the lack of space for the construction of personal facilities (ESMAP, 2011). King and Amponsah (2012) also add that the exclusivity engendered by city bylaws inhibit the slum dwellers from access these facilities at the household level. The result is an entrepreneur establishing income-generating ventures to supply the unmet needs.

Earnings of the Head Porters: Table 3 presents the income analysis of the head porters on good and worse days for the four areas of study. The income analysis revealed that on good business days, the head porters earned an average of GH\$4.1. However, about $44 \%$ of them earned below the minimum daily wage of GH $\$ 3.11$ which took effect from $1^{\text {st }}$ February 2010 . On worse performing days, the head porters earned an average of GH\$3.2 with about $49 \%$ earning below the minimum daily wage.

Table 3: Incomes earned by Head Porters on Good and Bad Days

\begin{tabular}{|c|c|c|c|c|c|c|c|c|c|c|}
\hline \multirow{3}{*}{$\begin{array}{l}\text { Income } \\
\text { earned } \\
\text { (GHd) }\end{array}$} & \multirow{2}{*}{\multicolumn{5}{|c|}{$\begin{array}{c}\text { Good Days } \\
\text { Percentage of Head Porters }\end{array}$}} & \multirow{2}{*}{\multicolumn{5}{|c|}{$\begin{array}{c}\text { Bad Days } \\
\text { Percentage of Head Porte }\end{array}$}} \\
\hline & & & & & & & & & & \\
\hline & Kejetia & $\begin{array}{l}\text { Race } \\
\text { course }\end{array}$ & Adum & $\begin{array}{l}\text { Central } \\
\text { market }\end{array}$ & Total & Kejetia & $\begin{array}{l}\text { Race } \\
\text { course }\end{array}$ & Adum & $\begin{array}{l}\text { Central } \\
\text { market }\end{array}$ & Total \\
\hline $1-3$ & 11 & 9 & 10 & 14 & 44 & 13 & 12 & 13 & 11 & 49 \\
\hline $3.1-5$ & 5 & 6 & 7 & 4 & 22 & 10 & 12 & 12 & 11 & 45 \\
\hline $5.1-7$ & 6 & 6 & 4 & 4 & 20 & 2 & 1 & - & 3 & 6 \\
\hline $7.1-9$ & 2 & 4 & 4 & 3 & 13 & - & - & - & - & - \\
\hline $9.1-11$ & 1 & 0 & 0 & 0 & 1 & - & - & - & - & - \\
\hline Total & 25 & 25 & 25 & 25 & 100 & 25 & 25 & 15 & & 100 \\
\hline
\end{tabular}

A comparative analysis of the head porters' earnings across the four clusters revealed that the head porters who operated within the Kejetia and Adum clusters were the highest earners on good business days earning an average of GH $\$ 4.19$ per day per head porter. On bad business days, Race Course cluster emerged as the most profitable with head porters earning an average of GH\$3.15 and in Adum and Kejetia GH\$3 and GH\$3.14 respectively (refer to Figure 2). The researchers sought to evaluate the economic motivation for migration by comparing the head porters' daily earnings to the average income per capita for the three sending regions of northern Ghana. The analysis revealed that the head porters' daily earnings were higher than the daily income per capita of 0.82 pesewas, 0.36 pesewas and 0.36 pesewas for the Northern region, Upper West region and Upper East region respectively (Ghana Statistical Service, 2005). This elucidates the incessant

\footnotetext{
${ }^{4}$ The exchange rate was GH $\phi 1$ to US $\$ 1$ as of 2010.
} 
movement of young women from the north to the south. It further validates the Harris-Todaro model of migration's claim that rural-urban migration is fuelled by the perceived high real wages in the urban areas.

Figure 3: Head Porters' Daily Earning across Clusters

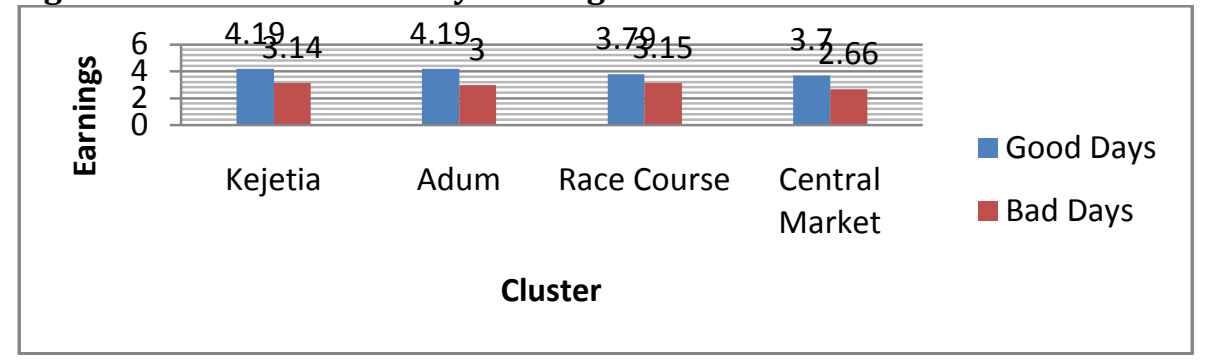

Although, most of the head porters started their work as early as 5.00 am and closed around $7.00 \mathrm{pm}$, there were periods when they had no wares to carry. A visit to the CBD revealed that most of the porters either slept under trees or chatted with one another during these lean periods of the day (see Figure 4).

Figure 4: A Head Porters resting on a non-busy working hour
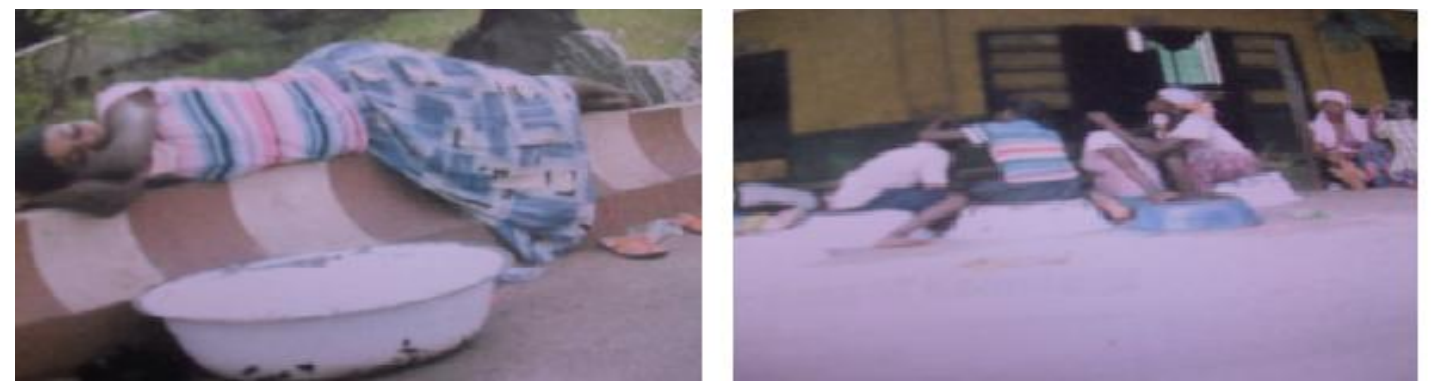

The analysis revealed that $83 \%$ of the head porters were able to save some of their earnings as presented in Table 4. Eighty percent of them were able to save up to GH\$1 on days when patronage for their services was high. About $27 \%$ of the porters saved with "susu collectors", while $40 \%$ of them saved with friends, and $2 \%$ and $14 \%$ saved with family members and kept the moneys on them respectively.

Table 4: Head Porters Daily Savings

\begin{tabular}{lll}
\hline Amount saved & Frequency & Percentage \\
\hline $\mathrm{GH} \$ 1$ & 66 & 79.5 \\
$\mathrm{GH} \$ 1.5$ & 1 & 1.2 \\
$\mathrm{GH} ф 2$ & 14 & 16.9 \\
$\mathrm{GH} \$ 3$ & 1 & 1.2 \\
$\mathrm{GH} \$ 4$ & 1 & 1.2 \\
Total & 83 & 100.0 \\
\hline
\end{tabular}

Challenges of Head Porterage in the Kumasi Metropolis: Opare (2003) identifies that these trusted friends and relatives with whom the head porters saved their earnings fail to account for the personal effects left in their custody. Similarly, the study identified that about $12 \%$ of the head porters have been unable to return home as planned due to the failure of these trusted relatives to account for their savings. The insecurity associated with these saving points increased their vulnerability and prolonged their stay in the cities. An investigation revealed that $56 \%$ of the head porters perceived their job as dangerous and mentioned the following reasons for that perception: injuries from falling luggage, car accidents and heavy load (see Figure 5). The head porters compete with traffic and pedestrians for the congested and limited walkways as indicated in Figure 5. The result is accidents, sometimes with fatalities (Yeboah and AppiahYeboah, 2009). 
Figure 5: Head Porters carrying Heavy Wares for their Clients

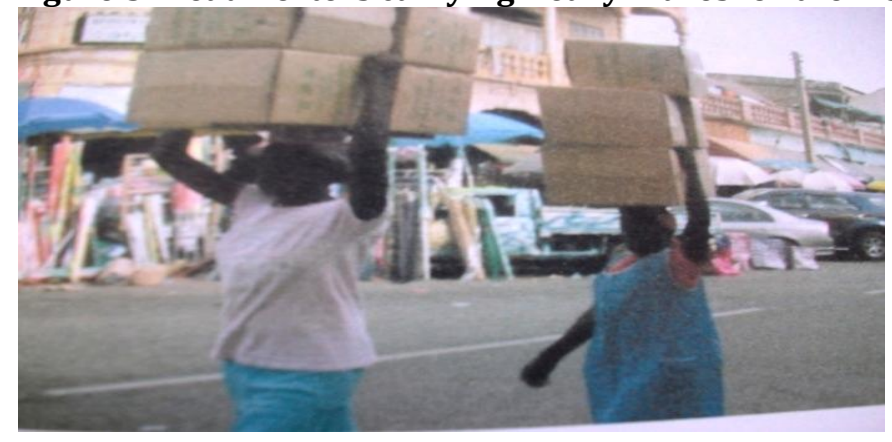

The other challenges as reported by $37 \%$ of the head porters were abuse such as insults, exploitation (i.e. cheating) and assault. Some of the head porters said:

"I once accidently dropped a client's luggage. The insults I received from her were unimaginable. The client eventually refused to pay me the amount we agreed upon. I could however not complain because I had earlier dropped her luggage". "Sometimes, customers refuse to pay me bargained amounts after they have realised that I cannot take their good back to where I took them from".

Twenty-nine percent of them also complained of harassment from tax collectors and city guards. Some of them also said: "Payment of tax in itself is not bad. City authorities do give us any assistance from the tax we pay and that makes it bad". Eighteen percent of the head porters complained of fatigue due to heavy loads with $16 \%$ complaining of other problems such as manhandling from male porters. Underpinned by these challenges which had earlier been identified by Agarwal et al. (1997), Beauchemin (1999 cited in Yeboah and Appiah-Yeboah, 2009) and Opare (2003), 91\% of the porters revealed their willingness to permanently return to their places of origin.

Coping Strategy: The researchers noticed that the head porters belonged to informal social groups to support one another in times of need. They met every Sunday of the week to discuss pertinent social issues. It is at such meetings that members' requests for support are tendered. It is common to see members contributing cash to help other members who are bereaved or are entering into marital unions. The associations also arrange to return any dead member home for burial. They also paid the hospital bills of members who were unable to pay after delivery. Any dispute that arose among members of the association especially those living in the slums were settled by the associations' executive. The executives also provided the required surety for members who required bill to be released from police custody. Intended to safeguard their image, they arrest members who indulge in criminal acts and refer them to the Police Service.

\section{Figure 6: Head Porters in a Meeting}

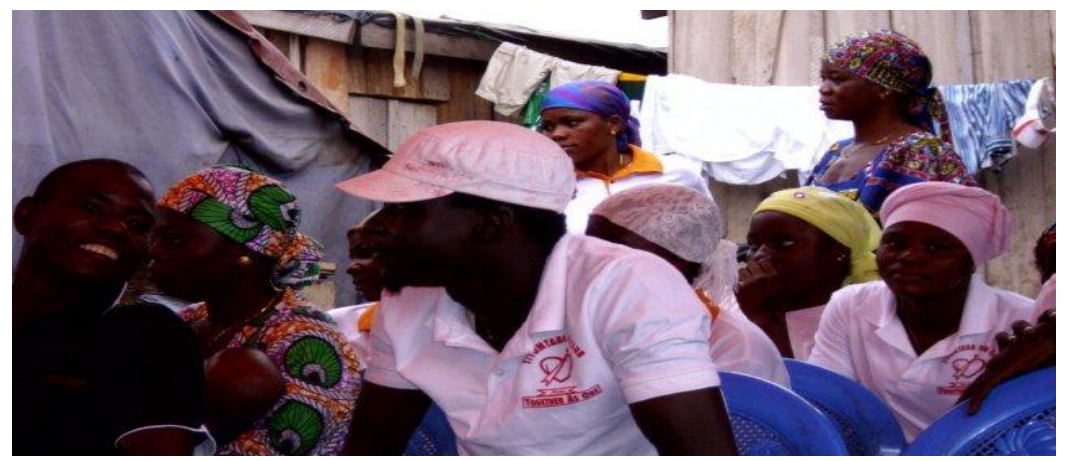


5. Conclusion and Recommendations: This section of the paper summarises the researcher findings based upon which some conclusion have been made towards improving living conditions of the head porters and bridging the development dichotomy between the north and south.

Conclusion: The researchers sought investigate the living conditions of female head porters in the Kumasi Metropolis. In achieving the purpose of the research, the authors interviewed 100 head porters operating within four clusters namely, Kejetia, Adum, Race Course and Central Market, in the Kumasi Metropolis. The survey results indicate that child labour is paramount in head porterage in the Kumasi Metropolis. The results revealed that $60 \%$ of the female head porters were less than 18 years old. The children drop out of school and migrate to the cities. The survey results revealed that only $34 \%$ of the head porters had completed basic school. The very young age in which the head porters begin their trade accounts for the low educational levels. In attempting to provide an explanation to why families allow these children to migrate to the cities to work at these tender ages, Kwankye (2011) indicates that child migration is a family investment. Adding to this is the fact that $93 \%$ of the head porters originated from the Northern region; a finding which is not unique as the region's dominance in the trade had already been established by earlier scholarly works (see Ghana Statistical Service, 2005; Awumbila, 2007; Kwankye et al., 2007). The exodus of the children from the northern region to the cities is blamed on the north-south development dichotomy. The study has established that the Kumasi Metropolis appears as an attractive destination for the migrant children a finding that tallied well with the Ghana Statistical Service's observation that Kumasi's social and economic endowment and the other cities are attractive to migrants. In this regard, economic reasons emerged as the major underlying factor for migration from the north to Kumasi. The economic underpinning of migration had already be established theories such as the Ravenstein migration hypothesis, the Lee's push and pull theory and HarrisTodaro migration model on migration. Study results also revealed an interesting reason for the female migration. Forty-seven percent of the head porters migrated to the Kumasi metropolis to work as head porters in order to be able to acquire kitchen and other household wares.

About the living the living conditions of the head porters, the results revealed that $49 \%$ of the head porters lived in wooden shacks in the slums with a room occupancy rate of four persons per room. These dwelling units are without the basic household facilities such as bathhouses, toilet and kitchen. Consequently, enterprises have emerged to supply the needs of the head porters. It is therefore common to see the head porters paying about 10 pesewas to access communal toilets and 10-15 pesewas to bath at the communal bathrooms in the slums. The study further revealed that the $14 \%$ of the head porters have contributed resources to rent single room apartments. The room occupancy rate of these single room apartments in the compound houses was five persons per room. Furthermore, 20 percent of them slept in stores after close of work while $14 \%$ lived in an abandoned factory structure. The analyses indicate that the head porters were less concerned about space in the rooms. Their concerned is to find space to sleep at night. Observation revealed that the occupants of wooden shacks and the abandoned factory lived under unhygienic environmental conditions and lacked most basic facilities that enhance human survival such as adequate water supply, toilet facilities and other life sustaining amenities. The survey results depict that selfmedication is prominent among the head porters. Eighty-seven percent of the head porters obtained health care from drug stores, pharmacy shops and drug peddlers. The common diseases suffered by the head porters were headaches (40\%), malaria (13\%) and body pains (37\%). They attributed these to the heavy wares they carry everyday in order to cope with the economic demands of the cities. Other diseases such as diabetes, rheumatism, eye problems and skin rashes were reported by $10 \%$ of the head porters.

Another health concern is the unsafe abortion the head porters indulge in. The result of the 10 snow-balled head porters depict that majority of them were not ready for children while others did not know who the fathers of their children would have been if they had gone ahead to give birth. This is summed up by the multiple sexual partners the female head porters had; a means of getting support. Another indicator for the examination of the head porters' living conditions was their nutritional status measured by the type of food they ate. The results indicate that $73 \%$ of the porters took three meals a day while $24 \%$ and $3 \%$ took two and one meal a day respectively. Despite satisfying the three meal requirement, the head porters were less concerned about balanced diet and the conditions from which they bough and ate the food. The survey revealed that about $95 \%$ of the head porters bought all their food from vendors who sold food along the streets. All the head porters met their water needs by fetching from public stand-pies at a fee. Ninety-one 
percent of them bought pipe borne water from private individuals at costs ranging from 10-15 pesewas per bucket (18 litres of cold water). All the above expenditure and other are met from the head porters' daily incomes of GH\$4.1 on good business days and GH\$3.2 on bad working days. Amidst the disparity in the daily earnings, the daily incomes on the good performing days was higher than the national minimum wage of $\mathrm{GH} \$ 3.2$. A comparative analysis of the head porters' earnings across the four clusters revealed that the head porters who operated within the Kejetia and Adum clusters were the highest earners earning an average of GH\$4.19 per day. However, on bad business days, the head porters who operate in the Race Course cluster earned the highest income of GH\$3.15. Notwithstanding the economic benefits of head porterage, the activity is bedevilled by several challenges include abuse by clients and sexual harassment from male porters. Consequently, $56 \%$ of the head porters consider the activity dangerous.

Recommendations: Following the findings, the authors maintain that interventions aimed at curtailing the phenomenon should be directed at both the receiving and sending areas. First and as a short-term measure, the Ministry of Women and Children Affairs, the National Youth Council and NGOs with interests in the welfare of children and women should collaborate each other to develop a database on the head porters so that programmes can be designed to enhance their welfare in the end. Decent hostels can be built to house them in the cities premised on the fact that the economic activity (head porterage) is in response to the lack of cost-effective means of transport between market centres and bus terminals in the cities. The Kumasi Metropolitan Assembly can enter into partnerships with other stakeholders to provide decent accommodation for the head porters and charge social rents towards maintaining the facilities. These will help improve the in humane conditions the head porters live in. The residential apartments erected by the Ghana Federation for the Urban Poor (GHAFUP) in Amui Dzor, Ashaiman through co-operate financing and with assistance from external partners can help make this proposal a reality. The assistance from People's Dialogue on Human Settlement collaborating with the Ministry of Works and Housing, GHAFUP has been able to construct a 31-unit residential block consisting of 26 single units and six flats for the slum dwellers at Amui Dzor in the Ashaiman Municipality in the Greater Accra Region. The Government of Ghana should introduce what the author's term as, "agricultural revolution" in the north. The Ghana Irrigation Development Authority should expand its irrigation projects in order to encourage the youth to go into dry season farming. This could be an antidote to the high incidence of poverty caused by the long dry seasons and failing yields due to climate variability. New genetic materials, particularly drought and disease resistant crops and livestock must be developed and deployed to the north.

Research institutions such as the Council for Scientific and Industrial Research (CSIR), the Grain Development Board, the Savannah Agricultural Research Institute and Universities should collaborate to develop receptive technologies to support all-year-round agriculture. The Burkina Faso vegetable industry remains a very good case from which lessons can be drawn to develop agriculture in the northern part of Ghana. Though located within the Sahel agro-ecological zone experiencing limited amounts of rainfall, Burkina Faso has been able to produce vegetables for export. The authors maintain that there exist useful lessons to be learned to improve the agrarian lives in the northern part of Ghana, which exhibit similar climatic conditions as Burkina Faso. The German Dreyer Foundation small reservoir project in Burkina Faso remains a very good case to study and replicate in Ghana. The small reservoirs can be managed effectively by organizing farmers into cooperatives to manage the water resource. With all-year-round productive activities, the number of migrants who move to the cities in the dry seasons to work would be reduced. Families will not force their children to move as an investment strategy. The re-introduction of the fertilizer subsidy program in Ghana is an added advantage. The rule-of-thumb should be equity and timely distribution of the commodity. The research ends with a recommendation to experts to look into the effects of the poor living conditions on the health status of the head porters. This research could not establish the relationship, if there is, between the living conditions and the morbidity cases the head porters reported. There should also be a research to validate the claim that some household allow their wards to migrate because the activities has emerged as a form of investment. In this work, the researcher will not only interview the head porters and validate the responses with what has been reported in literature, which used the same format but trace the head porters' origin and investigate the socioeconomic conditions of the households. This will be a source of information to triangulate the responses from the porters in the cities. 
Acknowledgement: The authors acknowledge the immense contributions of Dr. Imoro Braimah of the Department of Planning KNUST whose critical suggestions helped shape the manuscript. The authors are also grateful to Messrs Benjamin Dosu Jnr and Cornelius Nyamah who played kingpin roles in the collection of data for the research.

\section{References}

Adoma, M. O. (2009). The Living Conditions of Head Porters in the Kumasi Metropolis, an unpublished thesis submitted to the Department of Planning, Kwame Nkrumah University of Science and Technology in partial fulfilment of the award of Master of Science degree in Development Policy and Planning.

Adu-Okoree, B. I. (2012). Let us pause before sending them: an appraisal of the socio-economic condition of return migrants in Tamale, Ghana. Journal of Research in Peace, Gender and Development, 2(6), 149155.

Agarwal, S., Attah, M., Apt, N., Grieco, M., Kwakye, E. A. \& Turner, J. (1997). Bearing the Weight: The KayayooGhana's Working Girl Child. Centre for Social Policy Studies, University of Ghana, Legon, Accra.

Awumbila, M. (2007). Internal Migration, Vulnerability and Female Porters in Accra, Ghana. Department of Geography and Resource Development, University of Ghana, Legon, Accra.

Anzagra, S. \& Yeboah, T (2012). Child Migration in Ghana: Unveiling the Realities of Vulnerability and Social Exclusion, a paper to be presented at the KNUST Alumni Conference 29-31 AUGUST 2012 at Elmina, Ghana.

Baah-Ennumh, T. Y. \& Adom-Asamoah, G. (2012). The Role of Women in the Informal Economy of Ghana. Journal of Science and Technology, 32(2), $56-67$.

Berg, C. (2007). The Kayayei Survival in the City of Accra. Social Capital and Vulnerability in the Lives of Female Head Porters in Accra, Ghana. Unpublished MSc. Thesis presented to the International School for Humanities and Social Sciences, University of Amsterdam.

Bilsborrow, R. E., Oberai, A. S. \& Standing, G. (1984). Migration Surveys in Low Income Countries. Croom Helm, London and Sydney

Caritas Internationalis. (2012).The Female Face of Migration; Advocacy and best practices for women who migrate and the families they live behind. Caritas Internationalis working document, accessed from http://www.caritas.org/includes/pdf/backgroundmigration.pdf date accessed 16/07/2012.

Chant, S. (1998). Beyond Rural-Urban Divide. Journal of Environment and Urbanisation, 1, 5-10.

Duduchoge, S. (2003). Problems of Rehabilitating Teenage Kayayoos in Ghana. Unpublished MSc. (Planning) Dissertation presented to the Department of Planning, KNUST, and Kumasi

Energy Sector Management Assistance Program (ESMAP). (2011). Energy Access and Productive Uses for the Urban Poor, a survey implemented by the Energy Centre, College of Engineering, KNUST in 2011, unpublished.

Essel, S., Oppong, A. \& Salinas, E. (2007). A Look at Accra's Kayayei, A Special Report in The Statesman, Kokomlemle, Accra. 24 February 2007.

Feigben, J. (2010). Child Labour and Children's Education in Northern Region of Ghana: Case study of Bunkpurugu-Yunyoo and East Mamprusi Districts, an unpublished thesis submitted to the Department of Planning, Kwame Nkrumah University of Science and Technology in partial fulfilment of the award of Master of Science degree in Development Policy and Planning.

Ghana Statistical Service. (2005). Population Data Analysis Report; Socio-economic and Demographic Trends, 1, Accra, Ghana Statistical Service.

Ghana Statistical Service. (2007). Pattern and Trends of Poverty in Ghana 1991-2006, Accra, Ghana Statistical Service.

Hashim, I. M. (2005). Research Report of Children's Independent Migration from North Eastern Ghana to Central Ghana, Research Report. Development Research Centre on Migration, Globalisation and Poverty, University of Sussex: Brighton, UK.

Inkoom, D. K. B. \& Nanguo, C. Z. (2011). Utilisation of Irrigation Facilities towards Poverty Reduction in the Upper West Region of Ghana. Journal of Sustainable Development in Africa, 13(2), 335 - 351.

International Labour Organisation. (2004). International Programme on the Elimination of Child Labour. Child Labour, a Textbook for University Students, Geneva: ILO.

Kese, O. G. (2004). A Study of Programmes for Rehabilitation of Kayayei in the Kumasi Metropolis. Unpublished BSc. (Planning) special study submitted to the Department of Planning, KNUST, Kumasi. 
King, R. S. \& Amponsah, O. (2012). The Role of City Authorities in Contributing to the Development of Urban Slums in Ghana. In: Badu, E., Dinye, R., Ahadzie, O., Owusu-Manu, D. (Eds) Procs 1st ICIDA, March 2224, 2012, Kumasi, Ghana 736.

Kwankye, S. O., Anarfi J. K., Addoquaye, T. C. \& Castaldo, A. (2007). Coping Strategies of Independent Child Migrants from Northern Ghana to Southern Cities. Working Paper, Regional Institute of Population Studies (RIPS), Institute of Statistical, Social and Economic Research (ISSER). University of Ghana and Sussex Centre for Migration Research.

Kwankye, S. O., Anarfi, J. K., Tagoe, C. A. \& Castaldo, A. (2009). Independent North-South Child Migration in Ghana: The Decision Making Process in Working Paper T-29. Brighton, UK: Development Research Centre on Migration, Globalisation and Poverty.

Kwankye, S. 0. (2011). Independent North-South Child Migration as a Parental Investment in Northern Ghana. In. Boyle, P. J and Findlay, A. M. (edn) Population, Space and Place. John Wiley \& Sons, Ltd, http://dx.doi.org/10.1002/psp.682

Lee, E. S. (1966). A Theory of Migration. Demography, 3(1), 47-57

Lobnibe, I. (2010). Of Jong Migrants and Jongsecans: understanding contemporary rural out-migration from Northwest Ghana. Journal of Dagaare Studies, 7-10, 1-21.

Martin, P. (2003). Managing International Labour Migration in the 21st Century. South Eastern Eurpoe Journal of Economics, 1, 9-18.

Opare, J. A. (2003). Kayayei: The Women Head Porters of Southern Ghana. Journal of Social Development in Africa, 18(2), 33 - 48.

Ravenstein, E. G. (1885). The Laws of Migration. Journal of the Statistical Society of London, 48(2), 167-235.

Solem, M., Klein, P., Muñiz-Solari, O. \& Ray, W. (2011). AAG Centre for Global Geography Education. Available from http://globalgeography.aag.org. Date accessed 14/06/2012.

Stark, O. (1984). Migration Decision Making. Journal of Development Economics, 4, 239-265.

Todaro, M. P. \& Smith, S. C. (2012). 11th edition. Economic Development. New York, USA, Addison Wesley.

UNICEF. (2007). Incidence and Nature of Child Labour- The Big Picture. US Department of Labour Bureau of International Labour Affairs. Accessed from http://www.unicef.org/infobycountry/ghana.html Date accessed 02/03/2009

United States Department of State. (2009). Trafficking in Persons Report 2009 - Ghana, 16 June 2009, accessed from www.unhcr.org/.../country,,USDOS,,GHA,456d621e2,4a4214b9c,0.htm date accessed 5 April 2010.

Whitehead, A. \& Hashim, I. (2005). Children and Migration. Background Paper for DFID Migration Team.

Yeboah, M. A. \& Appiah-Yeboah, K. (2009). An Examination of the Cultural and Socio-Economic Profiles of Porters in Accra, Ghana. Nordic Journal of African Studies, 18(1), 1-21.

Yeboah, M. A. (2008). Gender and Livelihoods: Mapping the Economic Strategies of Porters in Accra, Ghana. Unpublished PhD Thesis. Department of Geology and Geography, Morgantown, West Virginia. 